\title{
Linguistic Politeness Analysis of Indonesia's Prominent YouTube Influencers
}

\author{
Rizmadina Amalia Shalekhah \\ Universitas Dian Nuswantoro, Semarang \\ email : rizmadina99@gmail.com \\ Septy Artika Estayani \\ Universitas Dian Nuswantoro, Semarang \\ email:septyartika@gmail.com \\ Melinda Sari \\ Universitas Dian Nuswantoro, Semarang \\ email:melynekap1@gmail.com \\ Raden Arief Nugroho \\ Universitas Dian Nuswantoro, Semarang \\ email: arief.nugroho@dsn.dinus.ac.id
}

\begin{abstract}
This paper aims to analyze the linguistic politeness of Indonesia's YouTube influencers. The findings show the type of YouTube content typology that has been found in this data according to Mediakix (2019) which gets a percentage of $40 \%$ is the type of interview content. This type of content is dominated by male Youtuber Meanwhile, according to Dynel (2015) theory, the category that gets the highest percentage in the category of insults with $43 \%$ of the total data. Based on a review of several studies, it was found that there are similarities and differences between one study and another. After analyzing the similarities and differences in previous studies, a novelty was found, namely in this study discussing the politeness patterns of YouTube influencers related to gender. Besides, this study analyzed 41 video sources which were used as research material. It can be seen that Indonesian Youtubers do not use polite language in order to trigger humour in its content. Interestingly, all humours made by these Youtubers contains politeness maxim deviation.
\end{abstract}

Keywords: politeness, maxim, linguistic, influencer, YouTube

JELTL (Journal of English Language Teaching and Linguistics), 5(3), 2020 


\section{Rizmadina Amalia Shalekhah et al.}

\section{INTRODUCTION}

Language is an important thing in human life. It can be seen that language is used every day by humans in various aspects of life and language is used by humans to convey a message and form communication between humans. Purba (2011) states that simply communication can mean an exchange activity between an information provider and an information recipient. In addition to that, the politeness maxim is the character of a nation. A polite nation is reflected in how polite the language is used in everyday life. Trihadmono et al., (2019) stated in his research that since people communicate all the time, politeness is needed in society to show respect for others, to maintain the relationships that have been built, and to look after faces to create comfortable interactions. Nowadays, the development of increasingly diverse and sophisticated communication media offers several conveniences in life, especially in terms of interaction with other people (Ambarwati et al., 2019). In addition to that, this development will inevitably lead to a diversity of changes, fluctuations and new phenomena, one of them is the phenomenon of language (Ambarwati et al., 2019). Therefore, social media can weaken or strengthen the intensity of the relationship between people and the community (Wellman \& Hampton, 1999).

Today, the young generation has many platforms to see their idols. However, as time goes by, the development of television has started to decline. Based on Nielsen's study in 2018 (in Fajar, 2019), it shows that although the length of time to watch television is still the highest, which is 4 hours 53 minutes per day on average, the length of time to access the Internet is the second-highest, with an average of 3 hours 14 minutes per day. This does not rule out that internet users are also YouTube users. Furthermore, Nielsen \& Sambrook (2016) also stated some things had changed related to people's habits in watching television. Nowadays, many people are changing their habit of watching television, starting from a conventional device and then switching to one of streaming web services such as YouTube. Therefore, Youtubers must be careful in speaking and behaving in videos uploaded on their YouTube channel. Consequently, if their fans or other people who idolize them, especially minors, see a video uploaded on a YouTube channel then there is a concern that they will imitate unethical things.

On that account, the use of language by Youtubers has a big impact on their subscribers. The role of language in the content is a tool that bridges the viewer's understanding of the visuals displayed. In using language as a communication tool, some rules must be obeyed by speakers and speech partners. Communicate means that the speakers do not only handover their content of information but also the way they handover it should not hurt the speech partners (Kingwell, 1993). Every speaker and speech partner is responsible for actions and deviations from linguistic principles in communication. Thus, speech partners must comply with the existing politeness maxim. Since these videos are watched and intended for all ages. This research should be conducted as an effort to form a political movement in the cyber world. If this research is not carried out, it is feared that the increasing of politeness maxim deviation in the cyber world will become something very ordinary or considered trivial. Moreover, the other research from Fitriyani \& Andriyanti (2020) stated that the language form used in the cyber world has an opportunity to be used by the students when they communicate with the teachers at school. 
Politeness maxim becomes a moral or basis for one's behavior. The purposes of the politeness maxim are to make both speakers and speech partners feel relaxed, confident, and comfortable to have a good social relationship (Mujiono \& Ula, 2020). According to Brown \& Levinson (1987), politeness is concerned with the "face" of speakers and speech partners. In this context, "face" is not interpreted as a physical form, but as self-respect in the view of society. So that it can be said that analyzing linguistic politeness is important to do. Since at this current time the use of words that are not polite has spread and become a habit among the public. Refers to Leech (in Culpeper, 2011) classified the politeness maxim into six parts, there are 1) minimize the benefit of self and maximize the benefit of others (the tact maxim); 2) minimize the benefit of self and maximize the harm of self (the generosity maxim); 3) minimize the scolding of other and maximize the praise of other (the approbation maxim); 4) minimize the praise of self and maximize the scolding of self (the modesty maxim); 5) minimize disagreement of other and maximize agreement of other (the agreement maxim); 6) minimize antipathy of other and maximize sympathy of other (the sympathy maxim).

Those politeness maxims prevent us from being rude to others. Various studies show that the principle of politeness can be maximally applied in the real world, but its effectiveness still needs to be tested again in the context of the cyber world on social media (Jumanto et al., 2016). Moreover, social media YouTube is associated with unlimited creativity. This is the challenge in this research so that creativity can coexist with politeness in the cyber world.

Based on the research of Astia (2020), it stated that the function of language is not only to communicate between people but also to show someone's feelings or emotions. While other research of Ernovilinda (2020), language is a communication instrument used by individuals to deliver ideas, messages, intentions, feelings, and opinions to others. All the data in this study is categorized as the politeness maxim deviation. It caused by the data is showing Youtuber's feelings or emotions. For instance, swearing, underestimating, mocking, etc. As the influencer YouTube, they have to understand that language is not only focused on the structure of the sentences but also the choice of words and speech etiquette. Thus, speech etiquette becomes important since it is an essential part of human interaction, behavior, and culture (Ryabova, 2015).

This research is very important to do, considering that at this current time, YouTube is one of the most popular online platforms in Indonesia, even the world. The objectives of this study include identifying the types of content material typologies used by YouTube influencers in Indonesia, identifying the types of linguistic impoliteness used and developing models of linguistic politeness that can be applied by YouTube content creators. The phenomenon of linguistic impoliteness that is often found in the mass media can be seen in the harsh language used (Markhamah, 2013).

\section{LITERATURE REVIEW}

This paper has examined several studies that have been carried out, especially regarding linguistic politeness patterns, namely as follows:

Dewi (2017) found one hundred and three speeches that deviate from the politeness maxim. The types of politeness maxim deviation found included: the tact maxim deviations 


\section{Rizmadina Amalia Shalekhah et al.}

are seven data, the generosity maxim deviations are six data, the approbation maxim deviations are forty-six data, the modesty maxim deviations are twenty-four data, the agreement maxim deviations are 12 data and the sympathy maxim deviations are eight data. Weaknesses in this research are stated that the source of data was taken from the 14 Youtubers video but in reality, the researchers included data from eleven Youtubers only.

This is appropriate with the findings of Embarsari (2019), which also found the same thing, there are five forms of impoliteness and six causes of impoliteness. The five types of impoliteness are (1) bald on record impoliteness; (2) positive impoliteness, (3) negative impoliteness, (4) sarcasm or mock politeness; and (5) withhold politeness. The six causes of impoliteness are (1) direct criticism with harsh words; (2) emotional boost from speakers; (3) protective opinion; (4) deliberately accusing speech partner; (5) deliberately cornered the speech partner; and (6) hiding information. The difference between the research of Embarsari (2019) and this research is the object of the study. In Embarsari (2019), it focuses on one Youtuber only, also called as subjective. Meanwhile, this research is general which includes Youtubers by including all kinds of impoliteness that aim to increase awareness of the impoliteness of other Youtubers.

Furthermore, it is different from the research owned by Sulistyawati et al., (2019). By using a qualitative descriptive method, this study produces five speech contexts in the Debat Kusir's video content by a YouTube account named Majelis Lucu. Among other things, namely contextual context, existential context, situational context, active context, and psychological context. The difference between Sulistyawati et al., (2019) and this study is on the source of the video. In this study, there are forty-one video sources used as the research object, while in the research of Sulistyawati et al., (2019) there are seven video sources.

On the other hand, Raihan \& Morelent (2019) had found fifty comments. There are twenty-two the generosity maxim deviations, thirteen the sympathy maxim deviations, ten the agreement maxim deviations, seven the tact maxim deviations, two the modesty maxim deviations, and no deviation of the approbation maxim are found. The weakness of this research is the author does not include examples of data that are deemed deviating from the politeness maxim, so that the readers cannot clearly understand what kind of comments are deemed deviating from the politeness maxim.

According to the results of previous research, Atma et al., (2019) had found data of the modesty maxim, nine data of the agreement maxim and three data of the sympathy maxim. At the event, there were also deviations of politeness, including two the tact maxim deviations, an approbation maxim deviation, two the generosity maxim deviations, two the modesty maxim deviations, five the agreement maxim deviations, and there were no sympathy maxim deviations. In this study, the weakness is the researchers do not show the table frequency on how often the maxims are obeyed or violated by the presenter on the Kompas TV YouTube Channel in November 2019 Period. So that readers cannot conclude how often obedience or violation occurred.

Pamungkas (2019) reported many YouTube video content uses profanity to entertain the viewers. One of them is the ludruk video content entitled Sarip Tambak Osa, uploaded from the YouTube account @ Upt. Audio Visual. This research uses descriptive qualitative research methods. Researchers also used the watch and note method in collecting data. Then, 
the researchers select data that considered deviating from the politeness maxim. Furthermore, the researchers classified the data using the theory of Leech (1983). In this study, the researchers stated there are six maxims based on the theory of Leech (1983), namely (1) the tact maxim, (2) the generosity maxim, (3) the approbation maxim, (4) the modesty maxim, (5) the agreement maxim and (6) the sympathy maxim. The researchers also found implicatures, they are (1) insulting, (2) expressing dislike, (3) threatening, (4) blocking, (5) ordering, (6) teaching, (7) refusing, (8) ) being crass, (9) arrogant, (10) disagreeing, (11) joking, (12) angry. In this study, the most common types of politeness maxim deviation are insulting and joking.

The similarity of this research with the previous is all data sources generally focus on speech. Whereas the difference with this research is on the previous researches are not included discussion of gender, does not categorize the type/typology of YouTube content, and only examines no more than 10 video sources. Meanwhile, this study includes a discussion of gender and examined 41 video sources from various Indonesian YouTube influencers.

According to Brown \& Levinson (1987) being polite means caring about the "face" of the speaker and speech partner. Brown \& Levinson (1987) have formulated the concept of the face slightly differently. According to them, the face is a personal symbol that everyone has and is universal. Each person is automatically required to glorify the face of themselves and others. Furthermore, according to Brown \& Levinson (1987), everyone must have a face and desires about positive things (positive face/want) and face and negative desires (negative face/want). The politeness strategy is used by the speakers to avoid acts of threatening face by the speech partner. As stated by Brown \& Levinson (1987), the act of threatening face is also known as the FTA (Face Threatening Act). More deeply, speech act strategies are needed in the context of speaking. Dynel (2015) has classified impoliteness into seven types, including:

\subsection{Disagreement}

According to Dynel (2015), disagreement is considered as behavior that is not marked even in the norms of the chosen communicative context, then it is considered to be very common in solving a problem (Angouri \& Locher, 2012).

\subsection{Insult}

Insult can be understood as a different type of speech activity includes speech that elicits negative characteristics of the target (Evaldsson, 2005; Ilie, 2001; Labov, 1972; Stokoe \& Edwards, 2007). According to Mateo \& Yus (2016), insult can have three functions: attack, praise, and bind socially.

\subsection{Taboo Language}

The topic of taboo or swear words (i.e., socially restricted polysemous words related to the field of taboo, especially religion, sex, and bodily functions), along with a prominent subtype of swearing (also known as an expletive), as reviewed by Jay \& Janschewitz (2008), Dynel (2012) and Christie (2013). In general, the three main functions of swearing can be distinguished, namely. social relations (also known as solidarity), catharsis (i.e., to vent one's 


\section{Rizmadina Amalia Shalekhah et al.}

frustrations or show one's pain), and aggression (which is usually expressed in verbal abuse/insults directed at the listener).

\subsection{Slur}

According to Dynel (2015), a slur is defined as a derogatory expression targeting (a group) of individuals selected regarding nationality, race, gender, sexual orientation among others, and usually having a neutral equivalent, capturing the same group but without contempt. The purpose of slurs is more varied and depends on whether they are used by ingroup and out-group speakers (Croom, 2013).

\subsection{Humor}

As stated by Dynel (2015), this type of impoliteness may occur when the concomitant threat of faces and humor is set for different listeners as independent communicative goals. Especially for viewers of television programs (Culpeper, 2005) intended to reap humorous rewards, validating the prevalence of (creative) immodesty in media discourse. On the other hand, Sulistyawati et al., (2019) stated that people use humor to warm the atmosphere, express happiness, cover up sadness, and many more.

\subsection{Sarcasm}

As Culpeper explains (in Dynel, 2013), he saw sarcasm as a narrow category of irony, which produces negative interpersonal effects. In other linguistic studies, however, sarcasm is seen as a broader concept that needs no center on mock modesty. Tarigan (in Dinari, 2015) stated that the main characteristic of the sarcasm language style is that it always contains bitterness and reproach that is bitter, hurtful, and unpleasant to hear.

\subsection{Deception}

According to Dynel (2015), deception has traditionally been defined as the cause the listener (continues) to maintain a false belief, something that the speaker believes to be false, what is objectively incorrect not necessarily. Furthermore, deception can be supposed as being morally wrong (Saul, 2012), insulting (Williams, 2002), and thus indicative of impoliteness.

\section{RESEARCH METHODS}

The research method is the well-structured framework that was built to plan the research under control (Aprianto, 2020). Also, in the research methods, the researchers were technically carried out by determining the research design, participants, instruments, and data analysis.

\subsection{Research Design}

This research is done by conducting a descriptive qualitative. According to Sutopo (2006), a qualitative research method with a descriptive approach is a study that describes indepth or in detail an actual condition that is happening in the real. The qualitative approach applied in this article is realized through the application of critical reviews of relevant 
literature (Nugroho, 2018). Next, the researchers analyze those data based on the theory from Mediakix (2019) and Dynel (2015).

\subsection{Participants}

Aims to see the linguistic impoliteness, the researchers collected data obtained from various Indonesian well-known YouTube channel in the past three years as primary data. As like as Majelis Lucu, Deddy Corbuzier, skinnyindonesian24, yb, Rans Entertainment, Arief Muhammad, dunia MANJI, Picky Picks, Uus Kamukita, Keanu Agl, Raditya Dika, Rachel \& Niko, Ericko Lim, Mabok Makan, Edo Putra Official, The Connell Twins, Vey Ruby Jane, and Adella Wulandari. Moreover, there also several Youtubers who were invited to be guest stars such as Jovial Da Lopez dan Andovi Da Lopez, Awkarin, Winson Reynaldi, Ferdian Paleka dan Jenda Munthe. Still, the researchers also took data from a channel that serves video content playing online games namely MILYHYA. Thus, the researchers took data from 25 total Youtubers, 19 channels, and 41 video sources which are deemed to contain the politeness maxim deviation in a certain episode. Then, the researchers got 104 total data.

Based on the various YouTube channel above, the information has been obtained that the average number of subscribers has reached more than one million. As stated by David et al., (2017) more than 500 channels on YouTube are of the Vlog type and according to SocialBlade.com (one of the social media statistics sites), Raditya Dika had occupied the first rank out of the 100 best channels in Indonesia, who is also based on Vlogs with more than 205 million videos watched time.

\subsection{Instruments}

In this study, the researchers did data collection by employing a non-participant observation (Aprianto, 2020). In other words, the researchers only carry out observational activities. The data of this research was taken from various Indonesian well-known YouTube channel. For instance, from YouTube channel namely Majelis Lucu get 36 data; from Deddy Corbuzier's channel get 17 data; from skinnyindonesian24's channel get 1 data; from yb's channel get 1 data; from Rans Entertainment's channel get 1 data; from Arief Muhammad's channel get 6 data; from dunia MANJI's channel get 1 data; from Picky Picks's channel get 1 data; from Uus Kamukita's channel get 1 data; from Keanu Agl's channel get 6 data; from Raditya Dika's channel get 3 data; from Rachel \& Niko's channel get 11 data; from Ericko Lim's channel get 2 data; from Mabok Makan's channel get 2 data; from Edo Putra Official's channel get 1 data; from The Connell Twins's channel get 2 data; from Vey Ruby Jane's channel get 3 data; from Adella Wulandari's channel get 2 data and the last from MILYHYA's channel get 6 data.

\subsection{Data Analysis}

The interactive analysis method used by the researchers refers to Sugiyono (2005). After sampling the data, next the data is reduced by classifying the type or typology of YouTube content according to theory from Mediakix (2019) and the linguistic impoliteness of YouTube influencers according to Dynel (2015). Data that does not include that classification has been reduced. After analyzing the data on the type/typology of YouTube content according to Mediakix (2019) and the linguistic impoliteness of YouTube 


\section{Rizmadina Amalia Shalekhah et al.}

influencers according to Dynel (2015), the data is presented in the tabulated form (looking for frequency of findings, patterns, etc.) and critical descriptions (critical arguments of researchers against linguistic phenomena. which exists). After getting the pattern of findings, the researchers conclude or verify the results of the study. It is the final stage in the data analysis process.

\section{FINDINGS}

In the finding section, the researchers took data from YouTube. Next, the researchers collected data obtained from various Indonesian well-known YouTube channel, in the past three years that aims to see the linguistic impoliteness. The various Indonesian well-known Youtubers are Majelis Lucu, Deddy Corbuzier, skinnyindonesian24, yb, Rans Entertainment, Arief Muhammad, dunia MANJI, Picky Picks, Uus Kamukita, Keanu Agl, Raditya Dika, Rachel \& Niko, Ericko Lim, Mabok Makan, Edo Putra Official, The Connell Twins, Vey Ruby Jane, and Adella Wulandari. Moreover, there also several Youtubers who were invited to be guest stars such as Jovial Da Lopez dan Andovi Da Lopez, Awkarin, Winson Reynaldi, Ferdian Paleka dan Jenda Munthe. Still, the researchers also took data from a channel that serves video content playing online games namely MILYHYA.

Based on the various YouTube channel above, the information has been obtained that the average number of subscribers has reached more than one million. The collection of data has been identified the politeness maxim deviations as classified by Dynel (2015). In addition to that, the researchers categorized YouTubers by gender, male and female. Then, it also has been categorized into types of YouTube content using a theory by Mediakix (2019). The following are the results of categorizing data that contain politeness maxim deviations.

\subsection{Male Youtubers}

\subsubsection{Type of Commentary YouTube Content}

According to Mediakix (2019), types of commentary is including vlog and conspiracy. Vlog is a video that contains opinions, stories, or daily activities that are usually written on blogs (Embarsari, 2019). Deeper, Embarsari (2019) also states that at this current time, vlog in great demand and watched by the general public through YouTube. Next, types of conspiracy is a content video that explores conspiracy theories around the world and meaning alternative explanations for some events (Mediakix, 2019). Here is an utterance example of commentary type:

\begin{tabular}{|c|c|}
\hline Utterance & Politeness Maxim Deviation \\
\hline "untuk apa kita berbudi pekerti, tapi miskin" & Insult \\
\hline
\end{tabular}

This utterance comes from Majelis Lucu, which consists of Coki Pardede and Tretan Muslim, who commented on a prank content belonging to Atta Halilintar. Fans of Majelis Lucu ask for Coki and Muslim to insult Atta Halilintar. Coki said that he saw a business opportunity here, in other words, content that insulted Atta Halilintar would get a lot of viewers. 


\subsubsection{Type of Product Reviews YouTube Content}

Product review is sharing a Youtuber's assessment after trying out some products (Mediakix, 2019). For instance, an unboxing content video. It captures a Youtuber's initial reaction as they open a product's packaging for the first time. This types of unboxing video allow audiences to variously experience the excitement of the new product. Below is an utterance example of product review content:

\begin{tabular}{|c|c|}
\hline Utterance & Politeness Maxim Deviation \\
\hline "lima ratus ribu dari mana nih bangsat" & Disagreement \\
\hline
\end{tabular}

The table above is an utterance by Coki Pardede in his video content on the Majelis Lucu channel while doing a product review of Oreo Supreme priced Rp. 500,000, with a look that he thinks is inappropriate for that price.

\subsubsection{Type of How-Tos/Tutorials YouTube Content}

As stated by Mediakix (2019), how-to/tutorial is educational in nature. A Youtuber will teach a task through some instructions and examples. Tutorials walk viewers through the ins and outs of a brand product or service, also sharing the detail of features and use-cases. Besides, how-to videos are including beauty, tech, cooking, and many more. The utterance example of how-tos/tutorials type is in the table below:

\begin{tabular}{|c|c|}
\hline Utterance & Politeness Maxim Deviation \\
\hline "dikit aja bro, fuck" & Taboo Language \\
\hline
\end{tabular}

Still comes from Majelis Lucu's channel, this utterance by Tretan Muslim while pours honey into the pork pudding that he cooked. Then, Coki Pardede warns him not to pour too much honey.

\subsubsection{Type of Comedy YouTube Content}

Different from the utterance examples before, in this type the researchers provide an example of data comes from a Youtuber who made a prank video content. The owner of a YouTube channel named Edo Putra Official uploaded a prank video that gave a pack of meat to a villager. However, the contents were not real meat, but trash. At the end of the video by Edo Putra Official, it is shown that he came over to the villager who had been deceived, then apologized and gave several bills. The researchers classified this example belongs to deception in the politeness maxim deviation.

\subsubsection{Type of Challenges YouTube Content}

In this type, Mediakix (2019) explains that challenge video will call for some followers to involve in a contest that aims to awareness or entertainment. Meanwhile, according to Rohmatun (2016), a video challenge is a kind of game where the players will be tested by something. It can be silly, scary, stressful, disgusting, embarrassing, or anything else that is essentially "risky". Usually, the players or the uploader will make all the viewers is intrigued 


\section{Rizmadina Amalia Shalekhah et al.}

or tempted and take on the same challenge. Here is the utterance example from the type of challenge:

\begin{tabular}{|c|c|}
\hline Utterance & Politeness Maxim Deviation \\
\hline "tau nggak gaya renangnya apa? Kayu ngapung " & Slurs \\
\hline
\end{tabular}

This utterance also comes from Majelis Lucu channel. A slur from Coki Pardede addressed to all participants of the Paralympic competition, where the participants have no hands and participating in a swimming competition.

\subsubsection{Type of Reaction YouTube Content}

This type of YouTube content typology aims to respond to an object or event. It purposes to provide information in mass communication and entertain the audience Cecariyani \& Sukendro (2019). Also, according to Azizah (2020), there are three indicators of community goals both as a Youtuber and a subscriber: 1) entertainment and relaxation; 2) interpersonal relationships; 3) friendship. Based on these two statements, it can be concluded that Youtubers and subscribers have an attachment that video content uploaded by a Youtuber can trigger various responses or comments from their subscribers. The table below is an example of a reaction type:

\begin{tabular}{|c|c|}
\hline Utterance & Politeness Maxim Deviation \\
\hline "anjing bocil nikah nyet" & Insults \\
\hline
\end{tabular}

This utterance comes from Bimo, the owner of a YouTube channel named Picky Picks. Bimo also uttered an insult to the video reaction on his YouTube channel while watching a video of young children having a marriage contract.

\subsubsection{Type of Q\&A YouTube Content}

According to Mediakix (2019), Q\&A is a video content where the Youtubers answer some questions from their viewers or subscribers. The Youtuber asks inquiries from their fans and then puts together a list of the most commons queries. Also, these types of video content can deepen the connection between YouTube influencers and their fans by providing a candid glimpse of their inner thoughts and a forum to talk about controversy. Here is the utterance example from the type of Q\&A:

\begin{tabular}{|c|c|}
\hline Utterance & Politeness Maxim Deviation \\
\hline "bangsat, anjing lo" & Taboo Language \\
\hline
\end{tabular}

An utterance comes from Keanu on his YouTube channel namely Keanu Agl. In this context, Keanu swearing because his friend disturbs him while he takes video content. Swearing usually as an emotive function is used to express the feeling of anger (Nugroho, 2019). 


\subsubsection{Type of Interview YouTube Content}

In the principle of politeness, the interview must not violate one of the six politeness maxims refer to theory by Leech (in Culpeper, 2011). They are the tact maxim, the generosity maxim, the approbation maxim, the modesty maxim, the agreement maxim, and the sympathy maxim. According to Marissa et al. (2019), it stated that in pragmatics are rules known as conversational maxims. By obeying the conversational maxims, it is expected that a conversation will take place effectively and efficiently. In addition to that, an impolite interview is an interview that speaks in an unclear voice and removes respect towards the speech partner or interviewer (Sukur, 2008). Lastly, one of the messages conveyed by a speaker to the speech partner is an ideology called politeness (Jumanto et al., 2017).

In this paper, the researchers compare two previous research from Dewi (2017) and Embarsari (2019). The results found some comparisons between the two studies. The research from Dewi (2017) had found six types of the politeness maxim deviations and the functions of politeness maxim deviation in Vlog (Video Blog) by Indonesian Youtubers. From that study, it also found one hundred and three the politeness maxim deviation in the form of utterances. The table below is an example of an interview type:

\begin{tabular}{|l|c|}
\hline \multicolumn{1}{|c|}{ Utterance } & Politeness Maxim Deviation \\
\hline $\begin{array}{l}\text { "kaya kalo kita nggak saling follow berarti nggak temenan } \\
\text { kan itu anjing banget ya" }\end{array}$ & Disagreement \\
\hline
\end{tabular}

The example above is an utterance spoken by Coki Pardede from Majelis Lucu channel. Coki Pardede thinks that two people who don't follow each other on their Instagram account means that there is no friendship between them.

\subsubsection{Type of Educational YouTube Content}

Educational video content offers the viewers pieces of information through thoughtprovoking, interesting, and cultural content (Mediakix, 2019). Furthermore, these videos often target specific demographics such as children or college students. Educational YouTube content help keep viewers informed or anatomize complex issues. Moreover, dissimilar from the utterance examples before, in this type the researchers provide an example of data comes from a Youtuber named Anji, the owner of dunia MANJI channel, who made deception in his video content that has been taken down.

Anji is a musician as well as a Youtuber. Anji asked a partner named Hadi Pranoto to make video content together. Hadi is part of an independent research team that studies and deepens microbiology. As quoted by Tribunnews from the live broadcast of Kompas TV, Monday (3/8/2020), Hadi Pranoto said that he was not a doctor and not part of the IDI. Then, Anji and Hadi Pranoto created a video containing the discovery of herbal medicine which is believed to be a cure for Covid - 19. However, these claims are considered false and must deal with the realm of the law. The researchers classified this video content belongs to deception in the politeness maxim deviation. 


\section{Rizmadina Amalia Shalekhah et al.}

\subsubsection{Type of Gaming YouTube Content}

According to Mediakix (2019), the process of this video content is to capture video gameplay by YouTube gamers and can take on various formats. For instance live streams, walkthroughs, tutorials, challenges, game reviews, or montages. Moreover, within the competitive niche, gaming videos are among the most-searched topics on YouTube. Below is an example type of gaming:

\begin{tabular}{|c|c|}
\hline Utterance & Politeness Maxim Deviation \\
\hline "fuck you" & Taboo Language \\
\hline
\end{tabular}

The example above is an utterance that comes from the YouTube channel namely MILYHYA. That utterance was spoken by the PUBG game player.

\subsection{Female Youtubers}

\subsubsection{Type of Commentary YouTube Content}

\begin{tabular}{|c|c|}
\hline Utterance & Politeness Maxim Deviation \\
\hline "to the point aja lah ya gausah banyak bacot" & Taboo Language \\
\hline
\end{tabular}

The example above comes from Vey Ruby Jane's YouTube channel. Vey told her friends to be quiet and ask immediately to eat noodles mix with ice cream.

\subsubsection{Type of Reaction YouTube Content}

\begin{tabular}{|c|c|}
\hline Utterance & Politeness Maxim Deviation \\
\hline "lu jadi cewe nyusahin lu goblok bangsat sia" & Insult \\
\hline
\end{tabular}

The utterance above comes from The Connell Twins, who are Indonesian twin Youtubers. Through the video commentary they uploaded, both of them clashed in responding to romantic chats with curses.

\subsubsection{Type of Interview YouTube Content}

\begin{tabular}{|l|c|}
\hline \multicolumn{1}{|c|}{ Utterance } & Politeness Maxim Deviation \\
\hline $\begin{array}{l}\text { "orang orang yang nggak berpendidikan gitu, yang otaknya } \\
\text { ga ada" }\end{array}$ & Sarcasm \\
\hline
\end{tabular}

The example above is an utterance spoken by Adella Wulandari, the owner of a YouTube channel namely Adella Wulandari. The context from that utterance is Adella Wulandari insulting all haters who criticized Dinar Candy, who also a Youtuber because her video content is discussing sex education. 


\subsubsection{Type of Gaming YouTube Content}

\begin{tabular}{|c|c|}
\hline Utterance & Politeness Maxim Deviation \\
\hline "binatang sumpah musuhnya, cuk!" & Insults \\
\hline
\end{tabular}

The table above is an example of a random comment that comes from MILYHYA YouTube channel. The speaker is one of the female game players.

Based on the analysis results of YouTube influencer about politeness maxim deviations in the data above, it can be described by the percentage of categorizing data using Mediakix (2019) theory as follows:

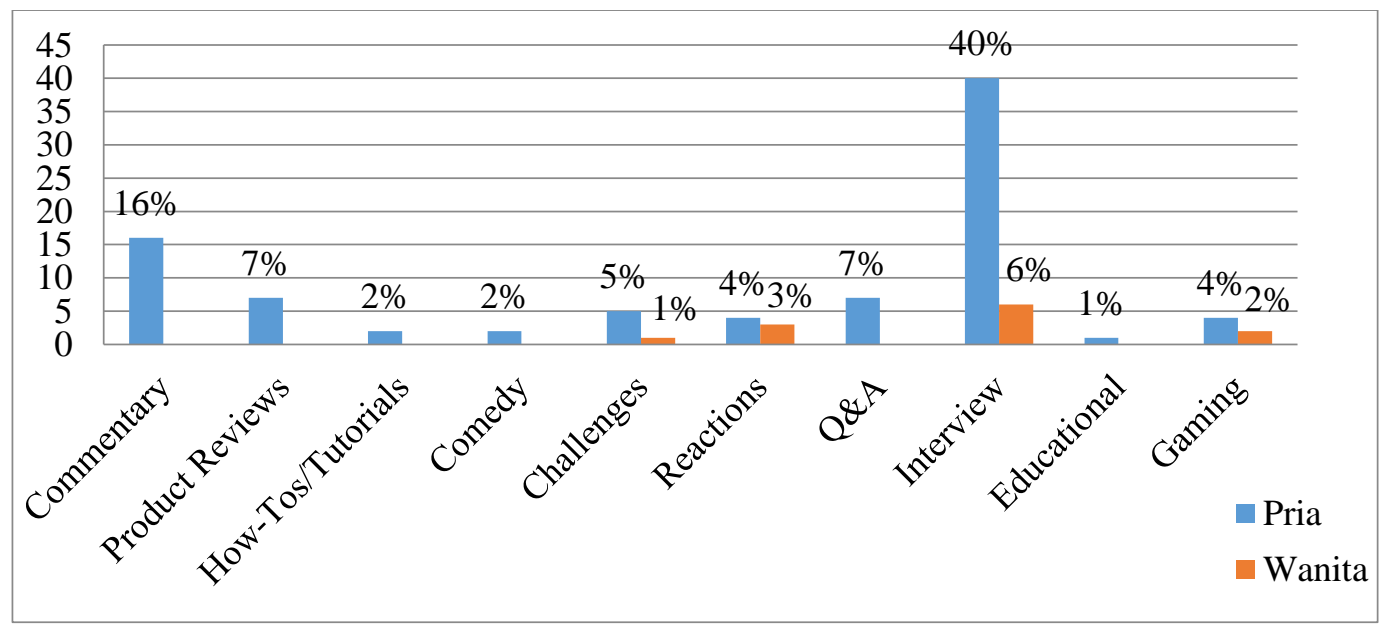

Figure 1 Findings of YouTube Categories and Their Deviations

From this picture, the researchers used the theory from Mediakix (2019). So that there are 10 types of YouTube content typology, there are comments, product reviews, howtos/tutorials, comedy, challenges, reactions, Q\&A, interviews, education, and playing games. Then, violations of linguistic politeness with the type of typology of interview content obtained the highest number of $40 \%$ which has been committed by male Youtuber. In addition to that, the researchers also described the results of the research above using theory from Dynel (2015) with the following percentage: 
Rizmadina Amalia Shalekhah et al.

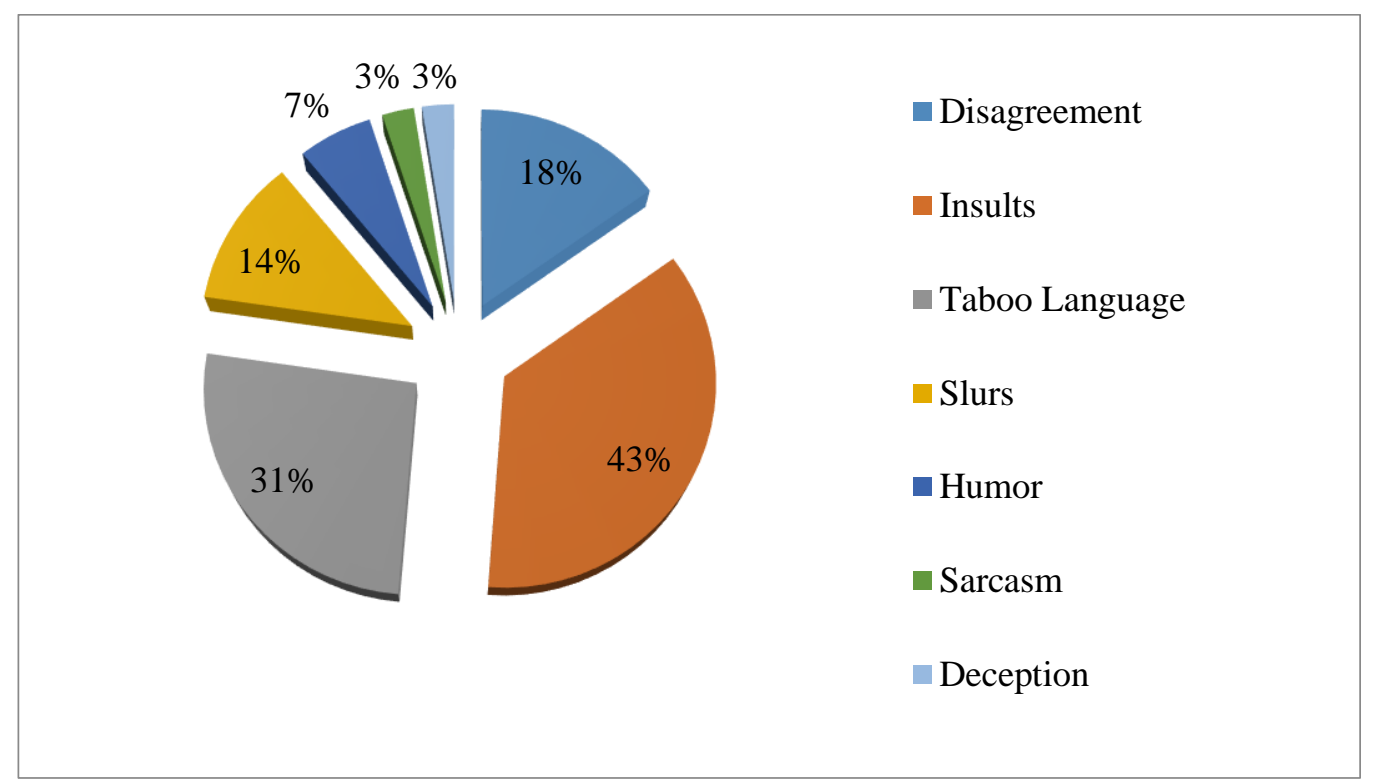

Figure 2 Findings of Politeness Maxim Deviations

The researchers use the theory from Dynel (2015) in classifying the politeness maxim deviation. In the picture above, there are seven types of politeness maxim deviation, they are disagreement, insults, taboo language, slurs, humor, sarcasm, and deception. So that the figure has been obtained by $43 \%$ in the types of insults.

In addition, the researchers also adding other findings. Leech (in Culpeper, 2011) classified the politeness maxim into six parts, there are 1) minimize the benefit of self and maximize the benefit of others (the tact maxim); 2) minimize the benefit of self and maximize the harm of self (the generosity maxim); 3) minimize the scolding of other and maximize the praise of other (the approbation maxim);4) minimize the praise of self and maximize the scolding of self (the modesty maxim); 5) minimize disagreement of other and maximize agreement of other (the agreement maxim); 6) minimize antipathy of other and maximize sympathy of other (the sympathy maxim). Based on journal research from Dewi (2017), the result stated there are six functions of politeness maxim deviation. Firstly, the functions of the tact maxim deviation are (1) threatening the speech partners, (2) accuse the speech partners, and (3) command the speech partners. Secondly, the functions of the generosity maxim deviation are (1) take advantage of the speech partner's ignorance, (2) take advantage of the speech partner's situation, and (3) defend oneself. Thirdly, the functions of the approbation maxim deviation are (1) teasing, (2) ridiculing, (3) lowering the dignity of the speech partner or others, (4) lowering the ability of the speech partner or others, (5) degrading the speech partner or physically of others, and (6) stating a comparison. Next, the functions of the modesty maxim deviation are (1) pride themselves on their wealth, (2) pride themselves on their abilities, and (3) show high self-confidence. After, the functions of the agreement maxim deviation are (1) expressing disapproval and (2) protesting against the speech partner's actions. Lastly, the functions of the sympathy maxim deviation are (1) show antipathy towards the speech partners and (2) show indifference to the speech partners or 
others. On the other hand, Embarsari (2019) found the five forms of impoliteness and the six causes of impoliteness. The five types of impoliteness are (1) bald on record impoliteness; (2) positive impoliteness, (3) negative impoliteness, (4) sarcasm or mock politeness; and (5) withhold politeness. The six causes of impoliteness are (1) direct criticism with harsh words; (2) emotional boost from speakers; (3) protective opinion; (4) deliberately accusing speech partner; (5) deliberately cornered the speech partner; and (6) hiding information.

\section{DISCUSSION}

Politeness in the language is one of the studies on pragmatics. According to the KBBI (Kamus Besar Bahasa Indonesia), politeness is defined as refinement and goodness (mind, language, behavior). Furthermore, politeness is a code of behavior that is established and agreed upon by a particular society, so that politeness is a prerequisite for human behavior to agree at the same time (Mislikhah, 2014). Linguistic politeness is very important to be applied to all content creators on social media, especially YouTube. Every content creators should pay more attention to linguistic politeness since their viewers of all ages allow to imitate things that may not good to do. Linguistic politeness has an important role in fostering the positive character of speakers, as well as showing the national identity (Zamzani et al., 2011).

Polite language activities require the fulfillment of several existing criteria. Firstly, it must qualify the cooperative principles. There are clarity, adequacy of elements, the correctness of content, relevance to the topic Brown \& Levinson (1987). Secondly, the implicature is almost understandable (Grice, 1975). Next, it must qualify the requirements of the politeness maxim. Lastly, it has to qualify the principle of mutual consideration and also qualify the principle of context. As content creators, these principles and criteria should be followed to produce quality content and be able to have a positive impact, especially in the field of linguistic politeness.

Based on research by Theodric (2019), Indonesian nowadays are more likely to watch video content on YouTube that they can spend their time with. In other words, Indonesian prefer to watch video content that serves entertainment. A content that serves entertainment on YouTube, including comedy content, there is often politeness maxim deviation occurs which aims to create humor that causes a laugh or smile response from the audience (Isnaeni, 2020). Unfortunately, content that deviates from the maxims of politeness can give a bad influence on the viewers. For instance, in the Majelis Lucu channel. Research from Isnaeni (2020). stated that Majelis Lucu serves content discusses things that being topic in society. The language used by the presenters, namely Tretan Muslim and Coki Pardede, which most people consider less polite. Therefore, the utterances of Tretan Muslim and Coki Pardede often being controversial in the public.

Thus far, the researchers have been found many politeness maxim deviation patterns in YouTube content. The goal of the content is just as entertainment means that can attract many viewers. Since the viewers tend to be more interested in Youtubers who use impolite language. Those politeness maxim deviations are deliberately carried out and have their function. Thus, it is the reason why this research has been conducted in the content of wellknown Youtubers in Indonesia. Also, this statement is supported by research from Dewi (2017). The result stated that deviations in linguistic politeness patterns in a Vlog made aims 


\section{Rizmadina Amalia Shalekhah et al.}

for commercial purposes and as entertainment means. In the research, Dewi (2017) considers that Youtubers deliberately use language that deviates from the politeness maxim patterns because it can attract the interest of viewers.

In digital development, especially on social media, there is an assumption that some strange and unusual things often become a trend and famous in a short amount of time. This reason underlies some content creators to commit linguistic impoliteness for their content to become trending on YouTube very quickly. According to research by Zamzani et al. (2011), it is stated that at this current time, verbal behavior is considered to have begun to pay no attention to the value of politeness and language politeness. Likewise in communicating via telephone, cellphone, and social media.

Referring to the findings above, the researchers have encountered or found politeness maxim deviation patterns according to Dynel (2015) by Youtuber with the male gender. More specifically, the content namely interview. Besides, according to the theory from Mediakix (2019), the most frequent occurrence type of YouTube content typology in the data above is insult. In line with the result before, Rasyid (2018) had found the politeness maxim realization of male students towards male and female teachers in Indonesian language learning interactions, both of them show obedience and deviations from the politeness maxim. On the other hand, male students often adhere to the principle of politeness with female teachers than male teachers. It shows that there are several gender influences shown in language learning interactions related to the politeness maxim.

\section{CONCLUSION}

Based on a review of various studies on impoliteness that have been carried out, the researchers conclude that previous studies related to linguistic impoliteness have in common that all data sources generally focus on speech. One of the interesting elements to study is the impoliteness used by Youtubers, which occurs in interview content using theory from Mediakix (2019) and gets a percentage of $40 \%$ is the type of interview content. This type of content is dominated by male Youtuber. Meanwhile, according to Dynel (2015) theory, the category that gets the highest percentage in the category of insults with $43 \%$ of the total data. Impoliteness on YouTube serves a purpose. The studies reviewed in this paper have not addressed this issue. Therefore, research on the impoliteness type of YouTube content typology used by Youtubers is considered interesting to do. This can also be a novelty in research since thus far no research includes a discussion of gender.

\section{REFERENCES}

Ambarwati, R., Nurkamto, J., \& Santosa, R. (2019). Phatic and Politeness on Women's Communication in Facebook: Humanistic Teaching Perspective of Being Polite in Social Media. Indonesian Journal of English Language Teaching and Applied Linguistics, 4(1). https://doi.org/10.22201/fq.18708404e.2004.3.66178

Angouri, J., \& Locher, M. A. (2012). Theorising Disagreement. Journal of Pragmatics, 44(12), 1549-1553. https://doi.org/10.1016/j.pragma.2012.06.011 
Aprianto, D. (2020). The Graphic Organizers ( GOs ) in the Development of Communicative Skills in Class Presentation. 5(2), 213-231.

Astia, I. (2020). Politeness Strategy in Interlanguage Pragmatics of Complaints by International Students. IJELTAL (Indonesian Journal of English Language Teaching and Applied Linguistics), 4(2), 349. https://doi.org/10.21093/ijeltal.v4i2.528

Atma, N. W., Hendriyanto, A., \& Mukodi. (2019). Kesantunan Berbahasa Pada Acara “ Aiman " di Kanal Youtube Kompas Tv Periode Bulan November 2019 (Kajian Pragmatik). 2019(November), 1-10.

Azizah, K. (2020). Konten Kreatif Youtube sebagai Sumber Penghasilan Ditinjau dari Etika Bisnis Islam (Studi Kasus Youtuber Kota Metro) (Vol. 21, Issue 1).

Brown, P., \& Levinson, S. C. (1987). Politeness: Some Universals in Language Usage. In Interactional Sociolinguistic.

Cecariyani, S. A., \& Sukendro, G. G. (2019). Analisis Strategi Kreatif dan Tujuan Konten Youtube (Studi Kasus Konten Prank Yudist Ardhana). Prologia, 2(2), 495. https://doi.org/10.24912/pr.v2i2.3735

Christie, C. (2013). The Relevance of Taboo Language : An Analysis of the Indexical Values of Swearwords. Journal of Pragmatics, 58, 152-169. https://doi.org/10.1016/j.pragma.2013.06.009

Croom, A. M. (2013). How to Do Things with Slurs: Studies in the Way of Derogatory Words. Language and Communication, 33(3), 177-204. https://doi.org/10.1016/j.langcom.2013.03.008

Culpeper, J. (2005). Impoliteness and entertainment in the television quiz show: The Weakest Link. Journal of Politeness Research, 1(1), 35-72. https://doi.org/10.1515/jplr.2005.1.1.35

Culpeper, J. (2011). Politeness and Impoliteness. Pragmatics of Society, 5, 393.

David, E. R., Sondakh, M., \& Harilama, S. (2017). Pengaruh Konten Vlog dalam Youtube terhadap Pembentukan Sikap Mahasiswa Ilmu Komunikasi. Acta Diurna, 4(1). https://ejournal.unsrat.ac.id/index.php/index/index

Dewi, I. K. (2017). Penyimpangan Prinsip Kesantunan dalam Vlog (Video Blog) Oleh Youtubers Indonesia. Jurnal Bahasa Dan Sastra Indonesia, 6(4), 519-539.

Dinari, I. (2015). Jenis-Jenis dan Penanda Majas Sarkasme dalam Novel the Return of Sherlock Holmes.

Dynel, M. (2012). Swearing Methodologically. The Impoliteness of Expletives in Anonymous Commentaries on YouTube. 10, 25-50.

Dynel, M. (2013). On Impoliteness and Drama Discourse: An Interview with Jonathan Culpeper. International Review of Pragmatics, 5(1), 163-188. https://doi.org/10.1163/18773109-13050107

Dynel, M. (2015). The Landscape of Impoliteness Research. Journal of Politeness Research, 11(2), 329-354. https://doi.org/10.1515/pr-2015-0013

Embarsari, I. F. (2019). Penyimpangan Prinsip Kesantunan Pada Vlog Awkarin (Kajian Pragmatik Culpeper). Sastra Indonesia, Linguistik.

Ernovilinda, E. (2020). Politeness Strategy in Shanghai Knights Film. IJELTAL (Indonesian Journal of English Language Teaching and Applied Linguistics), 5(1), 39-53. 
Rizmadina Amalia Shalekhah et al.

Evaldsson, A. C. (2005). Staging Insults and Mobilizing Categorizations in A Multiethnic Peer Group. Discourse and Society, 16(6), 763-786. https://doi.org/10.1177/0957926505056663

Fajar, T. (2019). Studi Nielsen: Pemirsa Indonesia Habiskan 5 Jam Nonton TV, 3 Jam Berselancar di

Internet. https://economy.okezone.com/read/2019/03/05/320/2025987/studi-nielsen-pemirsaindonesia-habiskan-5-jam-nonton-tv-3-jam-berselancar-di-internet?page $=2$

Fitriyani, S., \& Andriyanti, E. (2020). Teacher and Students' Politeness Strategies in EFL Classroom Interactions. IJELTAL (Indonesian Journal of English Language Teaching and Applied Linguistics), 4(2), 259. https://doi.org/10.21093/ijeltal.v4i2.473

Grice, H. P. (1975). Logic and Conversation. In Speech Acts (pp. 41-58). Brill.

Ilie, C. (2001). Unparliamentary language. May, 235. https://doi.org/10.1075/cilt.205.14ili

Isnaeni, N. L. (2020). Implikatur dalam YouTube Majelis Lucu Indonesia Konten Debat Kusir.

Jay, T., \& Janschewitz, K. (2008). The Pragmatics of Swearing. Journal of Politeness Research, 4(2), 267-288. https://doi.org/10.1515/jplr.2008.013

Jumanto, J., Rizal, S. S., \& Nugroho, R. A. (2016). Distant Language, Close, Language, and Impoliteness in the Indonesian Context. Journal of Global Research in Education and Social Science, 8(3), 131-137.

Jumanto, J., Rizal, S. S., \& Nugroho, R. A. (2017). Acting the Intangible: Hints of Politeness in Non-Verbal Form. English Language Teaching, 10(11), 111. https://doi.org/10.5539/elt.v10n11p111

Kingwell, M. (1993). Interpretation, Dialogue and Just Citizen.

Labov, W. (1972). Language In The Inner City: Studies In The Black English Vernacular. Philadelphia: University of Pennsylvania Press. 22(22).

Leech, G. N. (1983). Principles of Pragmatics. In Computation of Language (pp. 267-287). https://doi.org/10.1007/978-3-642-74564-5_12

Marissa, Sudjianto, \& Fitriana, R. (2019). Analisis Bentuk-Bentuk Pelanggaran Maksim Percakapan pada Manga CRAYON SHINCHAN Volume 01 Karya Yoshito Usui. 01, 110.

Markhamah. (2013). Prosiding Seminar Nasional "Ketidaksantunan Berbahasa dan Dampaknya dalam Pembentukan Karakter.” 978-979.

Mateo, J., \& Yus, F. (2016). John Benjamins Publishing Company. June 2014. https://doi.org/10.1075/jlac.1.1.05mat

Mediakix. (2019). The Most Popular Types of YouTube Videos. https://mediakix.com/blog/most-popular-youtube-videos/

Mislikhah, S. (2014). Kesantunan Berbahasa. Ar-Raniry, International Journal of Islamic Studies, 1(2), 285. https://doi.org/10.20859/jar.v1i2.18

Mujiono, M., \& Ula, A. L. (2020). Sociopragmatics Analysis of Politeness Strategy of the Main Character's Dialogues of Tinker Bell in Secret of the Wings Movie. Indonesian Journal of EFL and Linguistics, 5(2), 229. https://doi.org/10.21462/ijefl.v5i2.270

Nielsen, R. K., \& Sambrook, R. (2016). What is Happening to Television News? 
Nugroho, R. A. (2018). Peranan Filsafat Bahasa dalam Perkembangan Linguistik. Peranan Filsafat Bahasa Dalam Perkembangan Linguistik (The Role of Language Philosophy in the Development of Linguistics), 10-20.

Nugroho, R. A. (2019). Swearwords in Subtitling : A Case Study on Students 'Translation Project. 4(2), 141-149.

Pamungkas, Y. (2019). Penyimpangan Maksim Kesopanan Sajrone Video Youtube "Ludruk Sarip Tambak Osa”Dening Akun@Upt. Audio Visual.

Purba, A. (2011). Tindak Tutur dan Peristiwa Tutur. Pena: Jurnal Pendidikan Bahasa Dan Sastra, 1(1), 77-91. dis

Raihan, R., \& Morelent, Y. (2019). Prinsip Kesantunan Berbahasa dalam Kolom Komentar Media Sosial Youtube. 3(2), 2-6.

Rasyid, R. (2018). Analisis Kesantunan Berbahasa Berbasis Gender dalam Interaksi Pembelajaran Bahasa Indonesia di SMA Negeri 6. 1-18.

Rohmatun, M. (2016). 6 Jenis Video Penghasil Uang yang Paling Laris di Youtube. Para Vlogger Pemula Harus Tahu Nih! https://www.hipwee.com/tips/mau-dapatpenghasilan-dari-youtube-6-jenis-video-ini-bisa-kamu-jadikan-acuan/

Ryabova, M. (2015). Politeness Strategy in Everyday Communication. Procedia - Social and Behavioral Sciences, 206(November), 90-95. https://doi.org/10.1016/j.sbspro.2015.10.033

Saul, J. M. (2012). Lying, Misleading, and What Is Said: An Exploration in Philosophy of Language and in Ethics. Philosophy in Review XXXIII, 5.

Stokoe, E., \& Edwards, D. (2007). "Black this, Black that": Racial Insults and Reported Speech in Neighbour Complaints and Police Interrogations. Discourse and Society, 18(3), 337-372. https://doi.org/10.1177/0957926507075477

Sugiyono, P. (2005). Memahami Penelitian Kualitatif. Bandung: Alfabeta.

Sukur, S. G. (2008). Job Interview in English. IndonesiaTera.

Sulistyawati, D., Markhamah, \& Sabardila, A. (2019). Ketidaksantunan Bahasa Humor Dalam Akun Youtube Majelis Lucu Indonesia Pada Konten Debat Kusir.

Sutopo, H. B. (2006). Metode Penelitian Kualitatif: Teori dan Aplikasinya dalam Penelitian. Jakarta: Bumi Aksara.

Theodric, D. (2019). Konten YouTube Favorit Netizen Indonesia adalah "Sampah"? https://medium.com/darien-theodric/konten-youtube-indonesia-sampah-856337b1bf54

Trihadmono, E. J., Djatmika, Sumarlam, \& Nurkamto, J. (2019). Politeness Strategies: Negotiation in Procurement Service of Traditional Entertainments. IJELTAL (Indonesian Journal of English Language Teaching and Applied Linguistics), 3(2).

Wellman, B., \& Hampton, K. (1999). Living Networked On and Offline. Contemporary Sociology, 28(6), 648-654. https://doi.org/10.2307/2655535

Williams, B. (2002). Truth and Truthfulness: An Essay in Genealogy. Truth and Truthfulness: An Essay in Genealogy.

Zamzani, Musfiroh, T., Maslakhah, S., Listyorini, A., \& Rahayu, Y. E. (2011). Pengembangan Alat Ukur Kesantunan Bahasa Indonesia dalam Interaksi Sosial Bersemuka. 